\title{
A Player and Coordinator: The Versatile Roles of Eosinophils in the Immune System
}

\author{
Hai Long ${ }^{a}$ Wei Liao $^{a}$ Ling Wang $^{b}$ Qianjin Lua \\ ${ }^{a}$ Department of Dermatology, The Second Xiangya Hospital, Central South University, Hunan Key Laboratory of Medical Epigenomics, \\ Changsha, China; \\ ${ }^{b}$ Department of Stomatology, The Second Xiangya Hospital, Central South University, Changsha, China
}

\author{
Keywords \\ Eosinophil · Antigen-presenting cells · APCs · \\ Th2 immune response - Immunomodulation . \\ Effector cell functions . Thymic stromal lymphopoietin . \\ Helicobacter pylori
}

\section{Summary}

Eosinophils have traditionally been associated with allergic diseases and parasite infection. Research advances in the recent decades have brought evolutionary changes in our understanding of eosinophil biology and its roles in immunity. It is currently recognized that eosinophils play multiple roles in both innate and adaptive immunity. As effector cells in innate immunity, eosinophils exert a pro-inflammatory and destructive role in the Th2 immune response associated with allergic inflammation or parasite infection. Eosinophils can also be recruited by danger signals released by pathogen infections or tissue injury, inducing host defense against parasitic, fungal, bacterial or viral infection or promoting tissue repair and remodeling. Eosinophils also serve as nonprofessional antigen-presenting cells in response to allergen challenge or helminth infection, and, meanwhile, are known to function as a versatile coordinator that actively regulates or interacts with various immune cells including $T$ lymphocytes and dendritic cells. More roles of eosinophils implicated in immunity have been proposed including in immune homeostasis, allograft rejection, and anti-tumor immunity. Eosinophil interactions with structural cells are also implicated in the

Hai Long and Wei Liao contributed equally. mechanisms in allergic inflammation and in Helicobacter pylori gastritis. These multifaceted roles of eosinophils as both players and coordinators in immune system are discussed in this review.

(c) 2016 S. Karger GmbH, Freiburg

\section{Introduction}

Eosinophils develop from hematopoiesis in the bone marrow and migrate into blood, making up about $1-6 \%$ of white blood cells. These special granulocytes were first observed by Wharton Jones in 1846 and named by Paul Ehrlich in 1879, because they contain abundant intracellular granules that are intensely stained by the acidophilic dye eosin [1]. Therefore, eosinophils can be easily differentiated from other granulocytes such as neutrophils and basophils in morphology by their brightly brick-red appearance under hematoxylin and eosin staining.

Historically, eosinophils have long been perceived as important immune cells responsible for two aspects of events: i) combating multicellular parasites or helminthes, and ii) participating in hypersensitivity or allergic response, for example the pathological mechanisms of allergic asthma, along with mast cells. With an arsenal of toxic granule proteins and other pro-inflammatory mediators contained in its granules, eosinophils can cause tissue damage by its degranulation process upon inflammation-triggering signals. Therefore eosinophils have traditionally been considered as endstage cells in innate immunity that contribute to anti-parasitic immunity or allergy by their pro-inflammatory and destructive effects.

In the recent decades, many more new roles of eosinophils have been identified in various pathological processes, including not only host protection against other microbes, such as certain types 
of fungi, bacteria, and viruses, but also allograft rejection, anti-tumor immunity, and a number of idiopathic eosinophilic diseases [2-4]. These have dramatically enriched our knowledge on this specific granulocyte in regard to its functions and relevant molecular mechanisms in health and disease.

According to current understanding, apart from the pro-inflammatory and destructive effects as end-stage cells in innate immunity, eosinophils may also be involved in tissue repair, fibrosis, and remodeling as well as in modulation of adaptive immune responses [4-6]. Specially, eosinophils can actively promote Th2type immune responses by producing a range of immunoregulating cytokines and molecules [5] and acting as antigen-presenting cells (APCs) $[7,8]$. Eosinophils are also implicated in the mechanisms of allograft rejection [9] and anti-tumor immunity [10-12]. Here we will mainly review the multifaceted roles of eosinophils as both effectors and regulators of the immune system, with the molecular basis and functions discussed.

\section{The Biological and Molecular Basis of Eosinophil Functions}

Eosinophils are equipped with a preformed armamentarium of cationic granule proteins, cytokines, chemokines, growth factors, lipid mediators (e.g. leukotrienes, prostaglandins), and other immunomodulatory molecules, including matrix metalloproteinases, serving as the fundamental basis for the immunobiological functions of eosinophils [7]. Most of these products are stored primarily within intracellular granules or vesicles of eosinophils and can be secreted or released immediately in response to certain stimuli, affecting the immune microenvironment and causing relevant immune responses. Meanwhile, eosinophils express a broad variety of surface receptors and molecular makers, mediating signals in different immunobiological processes $[3,8]$. The different functional mechanisms associated with these eosinophil-derived products and eosinophil receptors have been comprehensively discussed in several previous reviews $[6,7,13,14]$ and thus will not be described here in detail. We just briefly summarize the different groups of molecules relevant to eosinophil functions.

\section{The Preformed, Functional Granule Contents and Eosinophil Degranulation}

Eosinophils are characterized by their numerous intracellular secretory granules in the cytoplasm, which store the majority of cationic granule proteins and a variety of cytokines, chemokines, and growth factors. Compared to T lymphocytes that require hours or days to generate and secrete cytokines upon activation, eosinophils can release their preformed granule contents by degranulation immediately when triggered by certain stimuli or signals through cell surface molecules.

Among these granule contents, eosinophil-derived cationic granule proteins include major basic protein (MBP), eosinophil- derived neurotoxin (EDN), eosinophil cationic protein (ECP), and eosinophil peroxidase (EPO). With a highly basic nature, these cationic proteins are highly toxic to parasitic helminthes and human airway epithelium because they can damage cells by binding to negatively charged cell membranes and thus disordering the lipid bilayer, or by affecting the activity of enzymes within tissues [15].

A variety of cytokines, chemokines, and growth factors are also harbored in the specific granules. These contents secreted by eosinophils can affect the immune microenvironment and function in several different aspects: i) the eosinophilopoietins, IL-5 and granulocyte-macrophage colony-stimulating factor (GM-CSF), and the key chemoattractant CCL11 (eotaxin) act on eosinophils themselves as an autocrine regulation [8], which plays critical roles in eosinophil chemotaxis and survival within tissues; ii) immunomodulatory cytokines such as IL-4 [16], IL-13 [16], and IL-25 [17] promote and/or enhance the Th2 immunity, participating in the pathogenesis of allergy and anti-parasite immune responses [5]; iii) pro-inflammatory cytokines such as IL-6 and tumor necrosis factor $\alpha(\mathrm{TNF}-\alpha)$ participate in the augment of inflammatory response and may cause tissue damage, indicating an immediatereaction role of eosinophils in innate immunity; and iv) transforming growth factor $\beta$ (TGF- $\beta$ ) enhances proliferation and collagen synthesis of fibroblasts and plays a crucial role in tissue remodeling and fibrosis, which are implicated in the chronic pathologic process of various eosinophil-associated inflammatory diseases, including asthma [18] and eosinophilic esophagitis (EoE) [19].

Eosinophils are a major source of lipid mediators such as leukotrienes, prostaglandins, and 5-hydroxyeicosatetraenoic acid (5HETE) as well as of platelet-activating factor (PAF), which have broad inflammatory effects. Besides, a number of proteinases, e.g. matrix metalloproteinase 9 (MMP-9), and other pro-inflammatory enzymes have been identified in eosinophils, many of which are implicated in the innate immune responses, including wound healing and tissue remodeling.

\section{Eosinophil Receptors and Surface Markers}

The eosinophil expresses a broad variety of surface receptors and molecular makers, each with specific roles to play. Comprehensive lists of these surface molecules as well as their corresponding ligands and biological functions have been previously summarized in several excellent reviews $[5,7]$.

According to their different immunobiological functions, we briefly summarize them in several groups as follows:

- Pattern-recognition receptors (PRRs): PRRs are surface molecules that help eosinophils to probe pathogens and/or host-derived damage signals. Namely, PRRs either directly recognize pathogen-associated molecular patterns (PAMPs), the specific microbial molecular signatures expressed by certain pathogens, or recognize damage-associated molecular patterns (DAMPs), the signals released by necrotic or damaged cells [20,21]. When responding to these pathogen- or tissue damage-related signals, 
Fig. 1. An illustration of the mechanisms involved in the immunomodulatory functions and the effector cell functions of eosinophils in Th2 immunity, a common immune response present in allergic inflammation and host defense against parasite infection. A. The eosinophil presents antigens to the Th cell. MHC class II molecules of the eosinophil present antigens to TCR receptors on the Th cell, producing 'Signal 1', and the costimulating molecule CD86 binds to CD28 of the Th cell, serving as 'Signal 2'. These signals promote the Th2 immune response characterized

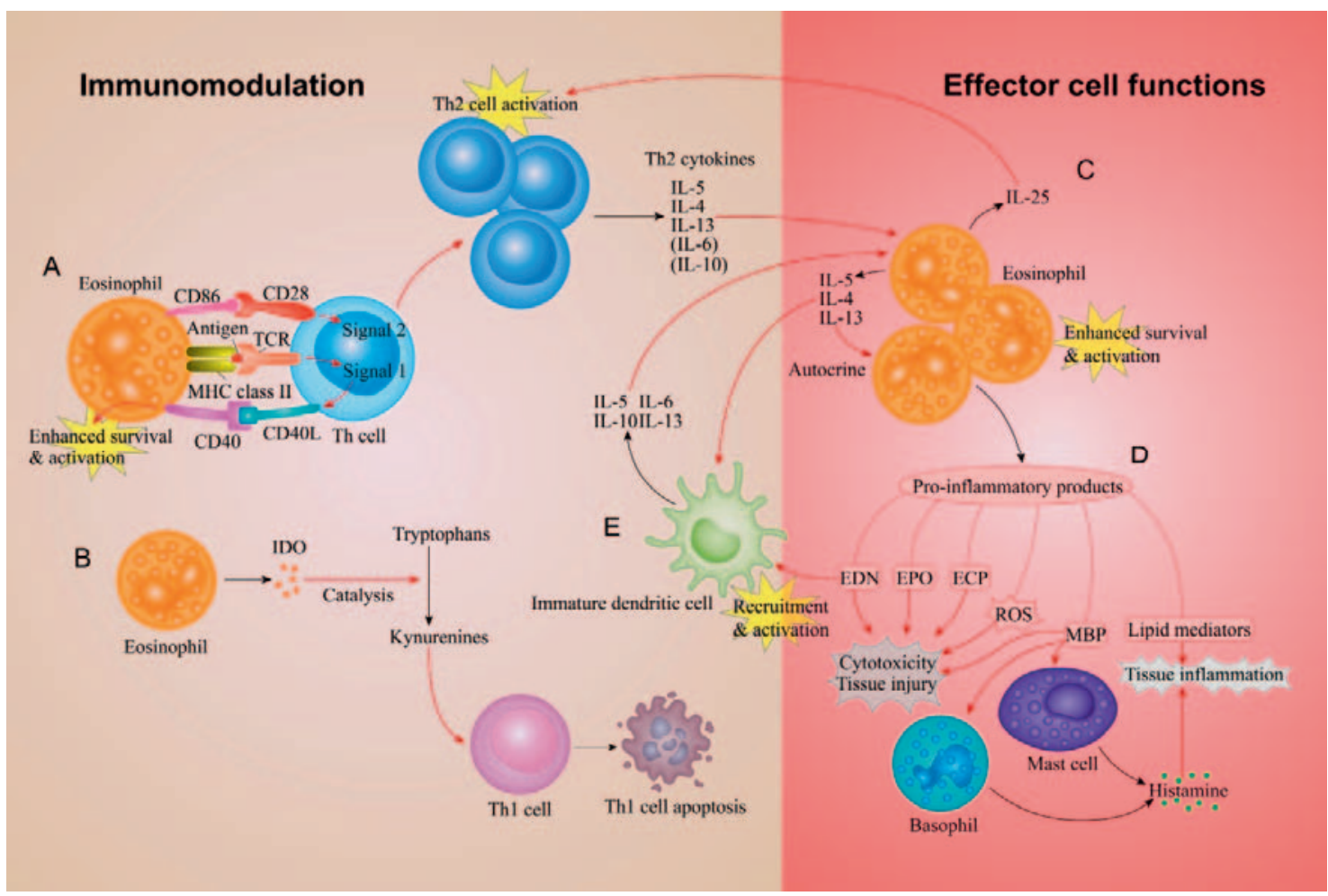
by Th2-cell activation and production of Th2 cytokines, i.e. IL-5, IL-4, and IL-13. Meanwhile, upon activation by the two signals, the Th cell expresses CD40L and binds to CD40 expressed on eosinophils, promoting eosinophil activation. B. Eosinophils express IDO, an enzyme that catalyzes the catabolism of tryptophans to kynurenines, which leads to Th1-cell apoptosis and thus favors the polarization of Th2 immunity. C. The regulatory effects of Th2 cytokines lead to eosinophil differentiation, recruitment, survival and activation. The activated eosinophils, in turn, release cytokines including IL-5, IL-4, IL-13, and IL-25, enhancing their own activity as an autocrine regulation and contributing to the Th2 polarization by regulating Th cells and immature DCs. D. Activated eosinophils release various pro-inflammatory products, including lipid mediators (e.g. leukotrienes), ROS, and granule proteins EDN, EPO, ECP, and MBP, which posing different effects such as cytotoxicity, tissue injury, and tissue inflammation. Of note, MBP can stimulate mast cells and basophils to release histamine, contributing to the tissue inflammation. E. EDN can also serve as an innate immune alarmin that recruits immature DCs and induces their differentiation into a Th2-promoting phenotype.

PRRs can activate downstream signaling cascades, leading to release of pro-inflammatory cytokines and type I IFNs [21].

- Cytokine receptors, chemokine receptors, adhesion molecules, and receptors for immunoglobulins, complements, proteases, and lipid mediators: These are implicated in, but not limited to, eosinophil development, adhesion and transmigration into tissues, chemotaxis, activation, and inflammatory responses [7, 22].

- Receptors involved in Th2 immunity: Major histocompatibility complex (MHC) class II [23] and the costimulatory receptors CD80, CD86 [24] and CD40 [25] are key molecules for eosinophils to present antigens to $\mathrm{T}$ cells and stimulate antigen-specific T-cell proliferation, initiating Th2-type immune response (fig. 1).

- Apoptosis-inducing or inhibitory receptors: These receptors expressed on eosinophils, e.g. sialic acid-binding immunoglobulin-like lectin 8 (siglec-8), serve as extinguishers of inflammation by inducing apoptosis of eosinophils. Siglec- 8 ligation with cross-linking antibodies can rapidly generate caspase-3-like activity and induce pronounced apoptosis of eosinophils [26].

\section{Eosinophils as Effector Cells in Innate Immunity: Pro-Inflammatory, Cytotoxic and Fibrogenic Effects}

\section{Pro-Inflammatory and Destructive Effects in Allergic Inflammation}

Eosinophil infiltration is a common feature in the pathologic sites of allergic inflammatory diseases, which is recruited and enhanced mainly by Th2-cell-secreted IL- 5 and eotaxin- 1 . For example, tissue eosinophilia is present in and tightly associated with the inflammation of the airway in asthma [27] and rhinosinusitis [28], of the gastrointestinal tract in eosinophilic esophagitis (EoE) [29, $30]$ and eosinophilic gastroenteritis [31, 32], and of the skin lesions in atopic dermatitis [33].

Eosinophils play key effector roles in the inflammation process provoked by allergens. Upon activation, eosinophils release its cytotoxic granule proteins and other granule contents via degranulation process. These released proteins, cytokines, and chemokines as well as lipid mediators and proteinases exert pro-inflammatory and destructive effects and cause inflammation or damage to the tissue (fig. 1). Notably, eosinophil granule proteins and reactive 
Table 1. Different mechanisms of eosinophil-mediated host defense against various types of microbial pathogens

\begin{tabular}{|c|c|c|c|c|}
\hline $\begin{array}{l}\text { Types of } \\
\text { antimicrobial } \\
\text { immunity }\end{array}$ & $\begin{array}{l}\text { Pathogen recognition } \\
\text { by eosinophils }\end{array}$ & $\begin{array}{l}\text { Eosinophil-mediated innate immune } \\
\text { responses }\end{array}$ & $\begin{array}{l}\text { Eosinophil-mediated adaptive } \\
\text { immune responses }\end{array}$ & Ref. \\
\hline Anti-parasitic & $\begin{array}{l}\text { eosinophils are } \\
\text { stimulated by sIgA-, } \\
\text { IgA- and IgG-coated } \\
\text { helminthes in vitro via } \\
\text { the immunoglobulin } \\
\text { receptor FcaR }\end{array}$ & $\begin{array}{l}\text { i) cytotoxic granule proteins (MBP, EPO, } \\
\text { ECP, and EDN) are released onto helminthic } \\
\text { parasites via eosinophil degranulation } \\
\text { (compound exocytosis), causing parasite- } \\
\text { killing effects; ii) eosinophils down-regulate } \\
\text { parasite-induced IgE responses and airway } \\
\text { goblet cell mucus production during } \\
\text { infection with Brugia malayi microfilariae }\end{array}$ & $\begin{array}{l}\text { eosinophils present parasite- } \\
\text { specific antigens to T cells, } \\
\text { promoting polarization of Th2 } \\
\text { response and production of } \\
\text { parasite-specific IgM; enhance } \\
\text { host immunity upon reinfection; } \\
\text { and promote schistosomiasis- } \\
\text { induced liver fibrosis by production } \\
\text { of profibrotic mediators IL-13 and } \\
\text { Th2 polarization }\end{array}$ & $\begin{array}{l}{[5,36,37} \\
131,132]\end{array}$ \\
\hline Anti-fungal & $\begin{array}{l}\text { eosinophil PAR-2 } \\
\text { receptor is cleaved by } \\
\text { aspartate proteases } \\
\text { produced by Alternaria } \\
\text { alternata, exposing } \\
\text { neo-ligands that } \\
\text { activate eosinophils }\end{array}$ & $\begin{array}{l}\text { the activated eosinophil adheres to the fungi } \\
\text { Alternaria alternata by the binding of its } \\
\text { CD11b integrin to the fungal cell wall } \\
\text { component, } \beta \text {-glucan, leading to eosinophil } \\
\text { degranulation and release of cytotoxic granule } \\
\text { proteins (MBP and EDN) and chemokines } \\
\text { (MIP-1 } \alpha, \text { MCP-1, IL-8) }\end{array}$ & N/A & {$[133,134]$} \\
\hline Anti-bacterial & $\begin{array}{l}\text { eosinophil surface } \\
\text { receptor PRRs, e.g. } \\
\text { TLRs, NOD-like } \\
\text { receptors, recognize } \\
\text { specific PAMPs } \\
\text { expressed on bacteria }\end{array}$ & $\begin{array}{l}\text { i) ingesting bacteria by phagocytosis, and } \\
\text { thereafter killing these bacteria in phagocytic } \\
\text { vacuoles with MBP and ECP translocated from } \\
\text { cytoplasmic granules; ii) bactericidal activity of } \\
\text { MBP and ECP, and (or) oxygen-dependent killing } \\
\text { by superoxide and EPO, towards extracellular } \\
\text { bacteria; iii) eosinophil extracellular traps, } \\
\text { comprised of mitochondrial DNA and granule } \\
\text { proteins, bind to and kill the trapped bacteria }\end{array}$ & N/A & {$[3,5,21,135]$} \\
\hline
\end{tabular}

MIP-1 $\alpha$ = Macrophage inflammatory protein 1 $\alpha$; MCP-1 = monocyte chemotactic protein 1; NOD = nucleotide-binding oligomerization domain; TLRs = Tolllike receptors; PRRs = pattern-recognition receptors; PAMPs = pathogen-associated molecular patterns; RSV = respiratory syncytial virus; PVM = pneumonia virus of mice.

oxygen species (ROS) cause direct injury to epithelial cells and other tissues [15]. Lipid mediators such as cysteinyl leukotrienes, enhance the airway smooth muscle contraction, mucus production and vascular permeability, and also promote the eosinophils' autocrine secretion of IL-4 [34]. Moreover, another two important effectors in allergic immune response, mastocytes and basophils, can be activated to release histamine upon stimulation by MBP, one of the eosinophil-derived cationic granule proteins [35].

The mechanism how eosinophil degranulation is triggered has been an intriguing question. Recent studies have found that epithelial cell-derived thymic stromal lymphopoietin and tissue stromal cell-derived IL-33 play crucial roles in modulating eosinophil infiltration and degranulation in the mechanisms of allergic inflammation. We will discuss these mechanisms later in this review in 'Epithelial or Tissue Stromal Cells, Eosinophils, and Allergic Inflammation'.

\section{Host Defense against Different Pathogens}

Traditionally, eosinophils have been recognized as the effector cells in killing parasites in the presence of antibody and/or complement, which was mediated by the cytotoxic granule proteins released onto the helminthes via eosinophil degranulation [5]. In re- 
cent decades, eosinophils have also been known as APCs and may enhance the parasite-specific immune response against helminthes such as Strongyloides stercoralis $[36,37]$. With regards to eosinophils' important role in modulation of the adaptive immunity, this will be discussed later in 'Immunomodulatory Functions of Eosinophils'. Apart from the anti-parasitic activity, eosinophils also participate in the host defense against other microbial pathogens, including fungi, bacteria and viruses, which have been discussed in detail in previously published reviews $[3,5,7]$. The different mechanisms of eosinophil-mediated host defense against these distinct pathogens are summarized in table 1.

\section{Response to Tissue Damage Signals and Promotion of Tissue Remodeling}

When alarmins or DAMPs are released from necrotic cells, the PRRs expressed on eosinophils recognize these endogenous danger signals and subsequently activate the eosinophil and enhance its survival [5]. For example, the binding to high mobility group box-1 (HMGB1), a necrosis signal molecule, by the receptor for advanced glycation end products (RAGE) expressed on eosinophils can mediate the chemotactic migration of eosinophils and their response to areas of tissue injury or necrosis [20]. It has been inferred that these effects might be beneficial to the healing of tissue wound or injury, especially for maintaining the epithelial barriers of gastrointestinal tract and airway.

However, a 'side effect' of this eosinophil response is the fibrogenic effect that may result in an outcome of tissue remodeling. Indeed, in some eosinophilic inflammatory diseases, including asthma, EoE, and certain eosinophilic skin dermatoses such as granuloma faciale, a pro-inflammatory effect of eosinophils often dominates in the early or acute phase, whereas a fibrogenic process gradually features the chronic phase in the pathological process [29, 38,39 ]. In these chronic inflammation settings, a broad spectrum of eosinophil-derived mediators, including TGF- $\beta$, Th2 cytokines (e.g. IL-13, IL-4), MMPs, and granule proteins MBP and EDN, play crucial roles in promoting epithelial and/or smooth muscle cell hyperplasia, myofibroblast differentiation, extracellular matrix reorganization and tissue fibrosis [5]. These effects contribute to a variety of chronic inflammatory conditions associated with eosinophilia, including not only airway remodeling in severe asthma [38, 40], stromal fibrosis in chronic rhinosinusitis with nasal polyposis [41] and esophageal subepithelial fibrosis in EoE [29] but also endomyocardial fibrosis in hypereosinophilic syndrome (HES) [42].

Angiogenesis is another feature involved in eosinophil-associated tissue remodeling. Several pro-angiogenic factors, such as vascular endothelial growth factor (VEGF), basic fibroblast growth factor (bFGF) and angiogenin, are also released by eosinophils, which contribute to the pathological process of eosinophilic inflammatory disorders. For example, these factors are associated with eosinophil infiltration in asthma and are implicated in the increase of peribronchial vessels and vascular permeability in the asthmatic airway $[40,43]$.

\section{Immunomodulatory Functions of Eosinophils}

\author{
Protecting the Immune Homeostasis: Roles in Bone Marrow, \\ Gut, and Thymus
}

Eosinophils are produced from pluripotent stem cells in the bone marrow, released into the peripheral circulation, and finally home into tissues such as the gastrointestinal tract, the thymus, mammary glands, and the uterus. The presence of eosinophils plays essential roles in maintaining the immune homeostasis in these tissues. For example, depletion of eosinophils in mice results in increased apoptosis of plasma cells in the bone marrow, while restoration of eosinophils can rescue this defect [44]. Indeed, eosinophils co-localize with plasma cells in bone marrow and secrete a proliferation-inducing ligand (APRIL), known as a critical plasma cell chemokine, and IL-6, sustaining the survival of plasma cells [44].

A major population of eosinophils is preserved in the gastrointestinal tract, regulating the immune homeostasis in the gut in various ways. First of all, eosinophils are implicated in the retention of IgA-producing plasma cells in Peyer's patches, also by secretion of APRIL [45]. This may play a role in the maintenance of microbial homeostasis of commensal organisms in the gut. Secondly, recent studies have shown that eosinophils in lamina propria are able to induce the differentiation of regulatory $\mathrm{T}$ (Treg) cells by producing TGF- $\beta 1$ and all-trans retinoic acid (ATRA) [46]. Moreover, in mouse models of acute peritonitis or acute colitis, eosinophil-deficient mice developed significantly more severe inflammation than wild-type mice, which suggests that eosinophils play protective roles in terminating acute inflammation, possibly due to their production of the anti-inflammatory lipids such as protectin D1 (PD1) $[47,48]$.

Eosinophils in the thymus may play important roles in the negative selection of $\mathrm{T}$ cells. In neonatal thymus, eosinophils have an activated phenotype and are localized primarily in the corticomedullary regions, which are the sites of negative selection of double-positive thymocytes [49]. However, these findings from mouse studies have not been confirmed in humans yet.

\section{Promoting Th2 Immune Response: Roles as APCs and Immu- nomodulators in Allergy and Anti-Helminth Immunity}

While the important roles of eosinophils as effector cells in Th2 immune response have been well documented, either in allergic inflammation or host defense against parasitic infection, eosinophils also play an active, modulatory role in the induction and propagation of Th2 immunity. It has been observed that, in a number of experiments with murine models of allergic airway inflammation induced by allergen challenge, depletion of eosinophils in mice results in significant inhibition of pulmonary T-cell recruitment, blockade of Th2-associated cytokine production (IL-4, IL-5, and IL-13) as well as in attenuated airway inflammatory outcomes such as pulmonary mucus secretion and/or the airway hyperresponsive- 
ness [50, 51]. Notably, adoptive transfer of eosinophils, together with Th2-polarized $\mathrm{T}$ cells or with delivery of eotaxin-1 into the lung, can restore the pulmonary T-cell infiltration, the Th2 immune responses, and the airway inflammation in these eosinophildeficient mice, while adoptive transfer of $\mathrm{T}$ cells alone does not show this reversal $[52,53]$. In addition, Th2-mediated peanut food allergy and anaphylaxis are impaired in eosinophil-deficient mice, and this defect can be restored by adoptive transfer of eosinophils into these mice [54]. Other studies focusing on anti-parasitic immunity have demonstrated that antigen-pulsed eosinophils, injected intraperitoneally into naive or immunized mice, are sufficient to induce the primary or boost the secondary Th2 immune responses to Strongyloides stercoralis in these mice, causing increased production of IL-4, IL-5, and the parasite antigen-specific immunoglobulins IgM and IgG [36]. Although there is lack of human data, these results provide compelling evidence for the crucial roles of eosinophils in the T-cell recruitment and Th2 immune response in allergen-induced inflammation and anti-parasitic immunity in mice. The possible mechanisms are discussed in the following, with both studies on humans and data from animal experiments.

\section{Eosinophils as Nonprofessional APCs}

In the recent decades, one of the breakthrough findings about eosinophils is their functions as APCs. APCs generally include two categories: professional APCs and nonprofessional APCs. Professional APCs, such as dendritic cells (DCs) and macrophages, constitutively express surface MHC class II molecules and costimulatory molecules, and are capable of processing antigen and presenting it to resting T cells. However, nonprofessional APCs, such as B cells and endothelial cells, usually do not express surface MHC class II molecules or costimulatory molecules unless activated by cytokines, and their functions of processing and presenting antigens also largely rely on cytokine-induced activation.

There has been sufficient evidence in human and murine models that eosinophils belong to the category of nonprofessional APCs in allergic inflammation and in anti-parasitic immune responses. Eosinophils in resting state do not constitutively express MHC class II molecules or costimulatory molecules (e.g. CD80/ CD86, CD40) on the surface and are unable to present antigens to $\mathrm{T}$ cells $[55,56]$. However, MHC class II molecules can be expressed on eosinophils upon activation by the cytokines GM-CSF, IL-4, IFN- $\gamma$ and IL-5 [55-58], and are also expressed on in vivo activated eosinophils isolated from the bronchoalveolar lavage (BAL) fluid of patients with eosinophilic pneumonia [23]. In addition, expression of costimulatory molecule CD86 (also known as B7.2) has also been identified on the surface of human eosinophils activated by IL-3 [59]. On the other hand, eosinophils are not fully competent in antigen processing even if stimulated by cytokines that signal via the $\beta$-chain, because eosinophils activated by IL- 5 or GM-CSF are only able to present superantigen and antigenic peptides, but not native antigens, to T cells $[58,59]$.

Data from murine studies are consistent with the above findings. Eosinophils isolated from mice infected with the parasitic nematode Brugia malayi [60] express MHC class II molecules. Activated eosinophils isolated from mice challenged by airway allergen [61] and eosinophils challenged by Strongyloides stercoralis antigens [62] also express the costimulatory molecule CD86.

The antigen-presenting function of activated eosinophils has been demonstrated both in vitro and in vivo. It has been observed that eosinophils treated with GM-CSF and IL-5 are able to present antigens to activated $\mathrm{T}$ cells, although much less efficiently than macrophages can $[55,58,63]$. As indicated by in vivo studies, eosinophils can express MHC class II and costimulatory molecules upon cytokine-induced activation, and stimulate antigen-specific CD4+ T-cell proliferation in a cell-cell contact manner, promoting Th2 cytokine production $[36,64,65]$. Meanwhile, CD40 on the surface of eosinophils can bind to CD40L, a costimulatory molecule expressed on the $\mathrm{T}$ cells upon signaling via antigen presentation process, leading to enhanced survival and GM-CSF release of eosinophils [25] (fig. 1).

Other Immunomodulatory Effects of Eosinophils Contributing to Th2 Immunity

Although the mechanisms are not completely clear, an immunomodulatory role of eosinophils in the induction and prosperity of Th2 immune response has been proposed. There is evidence that, in response to allergens or Th2-eliciting pathogens, eosinophil recruitment occurs prior to the infiltration of Th2 cells, i.e., in a manner independent of adaptive immunity $[66,67]$. In this early stage of response, eosinophils are a dominant source of the Th2polarized cytokines IL-4 and IL-13 (fig. 1), because these cytokines are preformed and stored in eosinophil granules and can be rapidly released upon stimulation. Meanwhile, the granule protein EDN released by eosinophils may serve as an alarmin to immature DCs, which induces the recruitment and differentiation of DCs into a Th2-promoting phenotype [68] (fig. 1). Recent studies have also suggested that the enzymatic activity of EPO, another eosinophil granule protein, promotes activation of DCs in vitro, activates intestinal and extraintestinal DCs in mice, and induces their mobilization to lymph nodes in vivo, which is necessary for Th2 priming [54]. On the other hand, indoleamine 2,3-dioxygenase (IDO), an enzyme constitutively expressed by eosinophils, catalyzes the conversion of tryptophans to kynurenines, which induce apoptosis of IFN- $\gamma$-producing T cells (Th1 cells), but not IL-4-producing T cells (Th2 cells) [69] (fig. 1). Thus all these regulatory effects favor the polarization of Th2 immunity at an early stage of immune response to allergen challenge or parasite infection.

Eosinophils may also exert a critical role in promoting polarization of Th2 immune response during allergic inflammation via cytokine IL-25. IL-25, released by eosinophils, enhances the expansion and cytokine production of the allergen-specific Th2 memory cells [17] (fig. 1). This regulatory effect on memory cells could be of crucial significance in Th2 immune response elicited by re-exposure of allergens or re-infection of parasites. Moreover, recent findings with in vitro experiments have indicated that eosinophils can modulate CD4+ T-cell responses via eosinophil-secreted HMGB1 in the pathogenesis of asthma [70]. 


\section{Regulating Other Activities in the Immune System}

Eosinophils also promote humoral immune responses. The IgM-mediated host protection against parasitic larval S. stercoralis is impaired in IL-5 knockout mice and can be rescued by reconstitution of eosinophils at the time of immunization [37]. Similarly, eosinophil-deficient mice also show inhibited production of antigen-specific IgM when immunized by alum antigen, while adoptive transfer of eosinophils into these mice can correct this defect in early antibody response [71]. These results have suggested a crucial role of eosinophils in augmenting B-cell activation and early antigen-specific IgM synthesis.

A recent study has evoked an interest in the role of eosinophils in helminth parasites-elicited protection against autoimmunity. Using mice with experimental autoimmune encephalomyelitis (EAE), a mouse model of multiple sclerosis, Finlay and colleagues [72] observed a clinical improvement with increased eosinophils after treating these mice with the parasitic Fasciola hepatica excretory-secretory products (FHES). However, this protection against EAE induced by FHES and the associated accumulation of eosinophils were absent in IL-33-/- mice and upon neutralization of IL-5, which, in turn, could be restored by transfer of FHES-induced or IL-33-induced eosinophils into these mice [72].

\section{Roles of Eosinophils in Allograft Rejection}

\section{Acute Allograft Rejection: Eosinophils Functioning as Effectors}

After the first observations of eosinophil infiltration of rejected allografts in transplant recipients, a number of studies have followed and collectively demonstrated the diagnostic and prognostic values of eosinophils in acute rejection of allografts. Weir et al. [73] have reviewed the clinical course of 132 consecutive renal transplant recipients and found that the elevated eosinophil counts in peripheral blood and/or increased presence of eosinophils in allograft biopsy specimens show an adverse prognosis for acute rejection outcome. Similar correlation with a poor prognosis was reported in other studies on patients receiving transplantation of kidneys [74, 75], livers [76, 77] or lungs [78].

The mechanisms how eosinophil infiltration in the allografts participates in allograft rejection have been investigated, mainly through experimental animal models [9]. Le Moine et al. [79] observed a dense, aggressive eosinophil infiltrate in the MHC class IIdisparate skin allografts that had been acutely rejected after transplanted in C57BL/6 mice. They also found that lymphocytes isolated from lymph nodes draining rejected skin allografts were primed for IL-5 secretion, and IL-5 mRNA was present within rejected allografts [79]. These results suggested a possible role of eosinophil infiltration in allograft destruction, dependent on IL-5 regulation, which was evidenced by the delayed rejection of the same skin allograft in IL-5-deficient mice. The destructive effect of eosinophils recruited into rejected allografts and its dependence on IL-5 were also identified in animals depleted of CD8+ T cells and transplanted with fully mismatched cardiac allografts [80]. Moreover, experiments in vitro shows that IL- 5 secretion can be inhibited by the presence of CD8+ T cells and/or IFN $-\gamma$, which is consistent with the in vivo experimental finding that eosinophilia is present in allografts rejected by IFN- $\gamma \mathrm{R}$-deficient recipients. On the other hand, studies on eosinophil-deficient $\triangle$ dblGATA1 mice transplanted with allogeneic heart grafts or allogeneic splenocytes have shown that eosinophils are not required for the formation or maintenance of alloantibody, namely, the donor-specific antibodies [81].

It is postulated that two possible mechanisms are involved in acute allograft rejection: CD8+ T-cell-mediated damage stimulated by IL-2, IFN- $\gamma$ or other cytokines, and eosinophil-directed tissue damage regulated by IL- 5 or other cytokines produced by CD4+ T cells $[9,77,82]$. Csencsits et al. [83] studied the CD4+ cell-mediated rejection response to indirectly presented alloantigen by transplanting cardiac allografts deficient for class II transactivator (CIITA) into recipient mice depleted of CD8+ T cells. Indeed, an acute rejection with a strong Th2 response characterized by eosinophil influx into the graft was observed in the BALB/c mice depleted of CD8+ T cells, whereas in recipients not depleted of CD8+ cells, these CIITA-/- allografts induced a polarized Th1 response instead [83]. Thus it is proposed that the role of eosinophils as effector cells in allograft damage becomes crucial when classical pathways of rejection are inhibited and Th2 cells dominate the alloimmune response. However, how the alloantigen was indirectly presented to CD4+ T cells remains to be elucidated.

Whether or not these possible roles of eosinophils and their mechanisms in murine models are the same in acute allograft rejection of humans remains largely unknown. A recent study with clinical data from 86 heart transplant patients has observed that patients with acute cellular rejection had a lower eosinophil count in peripheral blood compared with those without rejection, indicating an association between a high eosinophil count and nonoccurrence of allograft rejection [84]. This new finding challenges the traditional knowledge that elevated eosinophil counts predict adverse prognosis of allograft rejection. Further investigation into this paradoxical issue is warranted.

\section{Chronic Allograft Rejection: Regulatory Roles of Eosinophils in Alloimmunity}

Eosinophil infiltration is also implicated in chronic allograft rejection, but possibly playing a regulatory role in the alloimmune responses, which is different from its destructive roles in acute rejection. Nolan et al. [85] evaluated the presence of eosinophils with epifluorescence on Fisher-Giemsa-stained sections, which is a highly sensitive method, and found that, among the 15 examined patients with chronic renal allograft rejection, 14 (93\%) had eosinophil infiltration in the allografts. These infiltrated eosinophils were primarily localized in the intimal, adventitial, and tubulointerstitial compartments. Further, eosinophil-conditioned medium showed a stimulatory effect on DNA synthesis in both rat and human vascular smooth muscle cells, suggesting a potential regula- 
tory role of eosinophils in promoting intimal smooth muscle proliferation [85]. This might indicate a possible pathogenic effect of eosinophil-derived products in the pathogenesis of obliterative arteriopathy, a characteristic pathologic change in chronic vascular rejection of renal allografts, although it remains to be elucidated which cytokines or products released by eosinophils are the key molecules and how they impose the effect.

It has also been hypothesized that eosinophils, similar to NK cells, could induce maturation of DCs. When stimulated by CpG ODN 2395 (CpG-C), a surrogate molecule of PAMPs, eosinophils enhance DC maturation via a direct cell-cell interaction [86]. In addition, whereas the eosinophil granule protein EDN does not contribute to this maturing effect, $\mathrm{MBP}$, another granule protein released by these stimulated eosinophils, are taken up and internalized by DCs [86]. Thus it is hypothesized that eosinophils may be activated by host-derived DNA in the setting of necrosis-associated chronic inflammation and may subsequently induce DC maturation, contributing to the pathogenesis of chronic allograft rejection.

Le Moine et al. [87] established a mouse model of chronic rejection using C57BL/6 mice injected with the 145-2C11 anti-CD3 $\mathrm{mAb}$ and transplanted with MHC class II-disparate bm12 skin allografts. A marked infiltration of eosinophils and accumulation of IL-4 and IL-5 were present in the chronically rejected graft. Notably, the tissue eosinophilia and interstitial dermal fibrosis in these grafts were inhibited by in vivo blockage of either IL- 5 or IL-4, while the characterized obliterative intimal vasculopathy in these grafts could only be prevented by blockage of IL-4, but not IL-5 [87]. Apparently, the eosinophil involvement in chronic rejection may also be dependent on IL-5 and IL-4, possibly either with a role different to the other. However, mechanisms of this regulation still need further investigation.

\section{Roles of Eosinophils in Anti-Tumor Immunity}

Tumor-associated tissue eosinophilia (TATE) and/or presence of eosinophil degranulation have been observed for a long time in various cancers, including both solid tumors and hematological malignancies. While many studies suggested a favorable prognosis associated with tissue eosinophilia in different solid cancers, a poor prognosis was indicated in Hodgkin lymphoma with TATE [12], and the exact mechanisms of how eosinophils participate in antitumor immunity remain largely unclear and even controversial $[10,11]$. A variety of receptors and mediators expressed by eosinophils have been suggested to function in their anti-tumor activities. Briefly, eosinophils are proposed to exert anti-tumor effects either by direct cytotoxicity or by immunomodulatory functions in Th2 immune response, especially IL-4-mediated anti-tumor response $[5,12]$. However, there are also studies indicating the role of eosinophils in promoting tumors, e.g., by enhancing tumor angiogenesis and promoting the connective tissue formation adjacent to tumors [10]. Two recent reviews that discuss these mechanisms in an extensive magnitude are recommended for more detailed understanding of eosinophils' roles in anti-tumor immunity $[11,12]$.

\section{Recent Advances on Eosinophil Interactions with Structural Cells}

\author{
Epithelial or Tissue Stromal Cells, Eosinophils, and Allergic \\ Inflammation
}

\section{Regulation of Eosinophils by Epithelial Cell-Derived Thymic \\ Stromal Lymphopoietin in Allergy}

Thymic stromal lymphopoietin (TSLP), a cytokine mainly secreted by epithelial cells in response to allergen or other environmental stimuli $[88,89]$, is known as a key molecule in the development of allergic inflammatory response [90]. Increased expression of TSLP has been observed in the skin lesions of patients with atopic dermatitis [91, 92], in the nasal epithelium of patients with allergic rhinitis and nasal polyps [93], and also in airway epithelial cells in patients with allergic asthma being correlated with the severity of allergic inflammation in asthma $[94,95]$. TSLP has been linked with atopic dermatitis and allergic asthma also by the association with single nucleotide polymorphisms (SNPs) in the TSLP gene $[90,96]$.

For a long period, it is only known that TSLP mainly binds to the thymic stromal lymphopoietin receptor (TSLPR) expressed on myeloid DCs, by which the myeloid DCs are activated to polarize naive T cells into a Th2 phenotype [91]. More recently, research advances have indicated that eosinophils, expressing TSLPR, are also positively regulated by epithelial-derived TSLP, which contribute to the Th2-type immunity in allergic inflammatory response. Cook et al. [97] have observed that eosinophil expression of TSLPR is upregulated in the presence of TNF- $\alpha$ and IL-3, and thereafter TSLP directly activates eosinophils and leads to eosinophil degranulation, STAT5 phosphorylation, and increased eosinophil viability and survival. Experimental findings with mouse models also support the crucial roles of eosinophils in TSLP-induced systemic Th2 inflammatory response [98]. Meanwhile it is known that, in the presence of IL-3, TSLP significantly stimulates human hematopoietic progenitors via TSLP-TSLPR interactions to produce eosinophils and basophils colony forming units, promoting the involvement of eosinophils in allergic inflammation [99]. Another interesting recent finding is that TSLP can directly stimulate eosinophils to produce and release eosinophil extracellular traps, one of the efficient machineries for extracellular bacterial killing [100].

\section{Regulation of Eosinophils by Tissue Stromal Cell-Derived IL-33 in Allergy}

IL-33, a recently described cytokine of the IL-1 family, has also been recognized as an important mediator in Th2 immune response [101]. Expressed by tissue stromal cells in lung, skin and other tissues, IL-33 exerts diverse effects on different hematopoietically derived cell types by binding to a heterogeneous receptor complex consisting of IL-33R $\alpha$-chain (ST2L) and IL-1R accessory protein (IL-1RAcP) $[102,103]$. Both SNP in IL33 and its cognate receptor, IL1RL1 $[104,105]$ and increased expression of IL-33 in the airway epithelium [106], have been identified in patients with allergic asthma and have been shown to be associated with the de- 
velopment of this allergic inflammatory disease. In addition, airway inflammation is ameliorated in Il33-/- mice, and exacerbated in mice overexpressing IL-33 [107, 108].

Recent evidence has shown that eosinophils are regulated by IL-33 in the mechanisms of allergic inflammatory response. IL-33 can activate human eosinophils in vitro [109-111]. Upon its ligation to receptors on eosinophils, NF- $\mathrm{BB}$ and mitogen-activated protein kinase (MAPK) pathways are activated [110], promoting cell surface expression of $\beta 2$-integrin CD11b and intercellular cell adhesion molecule-1 (ICAM-1) and production of the pro-inflammatory cytokines IL-13, IL-6, and IL-8 [109]. More recent studies have demonstrated that dual-specificity phosphatase 5 (DUSP5), a member of mitogen-activated protein kinase phosphatases, negatively regulates IL-33-mediated extracellular regulated protein kinase activation, and thus abrogates IL-33-induced eosinophil survival and function [112]. IL-33 also directly stimulates eosinophil differentiation from CD117+ hematopoietic progenitor cells in an IL-5-dependent manner [113]. Studies in mice with allergic airway inflammation have observed an inhibitory effect of either antiIL-33 antibody or vaccination against IL-33 on eosinophil infiltration and the allergic inflammation, demonstrating an essential role of IL-33 in regulating eosinophilic inflammation $[114,115]$.

\section{Interaction between Gastric Epithelial Cells and Eosinophils in the Mechanisms of Helicobacter pylori Gastritis}

\section{Increased Eosinophil Infiltration in H. pylori Gastritis}

As early as in 1991, it was observed that H. pylori-positive chronic gastritis had significantly greater eosinophil infiltration and degranulation in gastric mucosa than $H$. pylori-negative chronic gastritis or normal individuals [116]. Consistent findings were confirmed in a larger sample size by a later study with specimens from $44 \mathrm{H}$. pylori-positive patients and $20 \mathrm{H}$. pylori-negative patients [117]. In specimens of chronic $H$. pylori gastritis, the severity of gastritis was significantly correlated with that of eosinophil infiltration [116], although no difference in the severity of eosinophil infiltration was observed between gastritis with ulcer and those without gastric ulcer among $H$. pylori-positive patients [117]. Another intriguing phenomenon is that eosinophil infiltration in the gastric mucosa remains at a relatively high level even at 1 year after therapeutic clearance of $H$. pylori [118]. These data implied a possible link between $H$. pylori infection and tissue eosinophilia in the inflammatory process present in H. pylori gastritis. However, the mechanisms remain largely unknown until recent studies have shed light on mechanisms of the host-bacterium interaction in the gastric mucosa through which $H$. pylori regulates eosinophil recruitment and degranulation.

\section{H. pylori, Gastric Epithelial Cells, and Eosinophils: Interactive} Roles in the Mechanisms of $\mathrm{H}$. pylori Gastritis

The crosstalk between $H$. pylori and gastric epithelial cells not only causes epithelial cell inflammatory injury, but also impacts on eosinophil infiltration and function in $H$. pylori gastritis (fig. 2).
Gastric epithelial cells exposed to $H$. pylori for 24 h can overproduce the chemokines CCL2, CCL5, and GM-CSF, which serve as chemoattractants and enhance eosinophil recruitment to colonized gastric mucosa. It has been further confirmed that these chemokine production and eosinophil recruitment effects are mediated by MAPK pathway in gastric epithelial cells, and also by the cag pathogenicity island of $H$. pylori [119], a strain-specific virulence locus associated with enhanced risk of peptic ulceration and gastric adenocarcinoma [120].

H. pylori outer membrane vesicles (OMVs), which refer to the vesicular compartments derived from the bacterial outer membrane and released from the $H$. pylori bacteria, are considered as key factors in the mechanisms of eosinophil degranulation affected by $H$. pylori infection. OMVs contain surface elements of the bacterium such as lipopolysaccharide (LPS), and act as a vehicle for vacuolating cytotoxin (VacA) of the bacterium [121]. Uptake of $H$. pylori OMVs by gastric epithelial cells can cause apoptosis, release of the pro-inflammatory cytokine IL-8 [121], and increased expression of ICAM-1 on cell surface [122]. Eosinophils recruited from the lamina propria of gastric mucosa, expressing the $\beta 2$ integrin CD11b/CD18, can recognize the ICAM-1 molecules and interact with gastric epithelial cells to cause degranulation [122]. H. pylori OMVs can also directly trigger the release of granule proteins from human eosinophils by an ICAM-1- and CD11/CD18-dependent mechanism [122].

Meanwhile, a recent study has proposed that eosinophils may play a role in the repair of gastric mucosa tissue during $H$. pylori infection. Exposure to the H. pylori-derived peptide $\mathrm{Hp}(2-20)$ stimulates eosinophil migration and production of VEGF-A and TGF- $\beta$, which are two key mediators for tissue remodeling [123]. In vivo experiments also found that $\mathrm{Hp}(2-20)$ could cause eosinophil infiltration in rat gastric mucosa with indomethacin-induced injury [123].

\section{Future Directions}

Research advances in the recent decades have fundamentally broadened our understanding of eosinophil biology and its multifaceted roles in immunity. Advances in eosinophil biology have also shed light on a series of potential therapeutic targets, such as IL-5 and siglec-8, for eosinophilic diseases including allergic asthma $[124,125]$. Inspiringly, a series of novel drugs or monoclonal antibodies (mAb) that specifically inhibit eosinophils have come into the horizon $[124,126]$. For example, mepolizumab, the first anti-IL-5 mAb applied in clinical trial for treating asthma, has proved to be effective in both inhibiting eosinophilia and reducing exacerbations rates in asthma [127].

Challenges, however, still remain in current research heading to decipher the various effects of eosinophils and their exact mechanisms in different immunobiological milieus. These difficulties are largely due to the complex immune regulation network, e.g., in the sophisticated scenarios like allograft rejection and anti-tumor immunity. Moreover, the origin and the mechanisms of eosinophilia 
Fig. 2. The role of eosinophils and its mechanisms in $H$. $p y$ lori gastritis. A. OMVs continuously shed from the surface of $H$. pylori in the gastric lumen. OMVs contain LPS and VacA. Part of H. pylori form biofilms on the surface of gastric epithelium. B. Upon the uptake and internalization of $H$. pylori OMVs, gastric epithelial cells show increased apoptosis and release of IL-8, causing pro-inflammatory effect. C. Internalization of $H$. pylori OMV causes gastric epithelial cells to actively express ICAM-1 and release

chemokines CCL2, CCL5, and GM-CSF that recruit eosinophil migration from the lamina propria to the epithelium. D. Infiltrated eosinophils, expressing the $\beta 2$ integ-

rin $\mathrm{CD} 1 \mathrm{~b} / \mathrm{CD} 18$, are stimulated by the gastric epithelial cells via binding to ICAM-1, leading to eosinophil degranulation and IL-8 production, which contributes to the inflammatory response. E. Eosinophils can also transmigrate through the epithelium into the gastric lumen, where contact with $H$. pylori OMVs may stimulate eosinophil expression of CD11b/CD18, release of RANTES and IL-8, and also eosinophil degranulation, participating in the inflammatory response. F. $H$. $p y$ lori can probably induce eosinophils in the gastric lumen to produce VEGF-A and TGF- $\beta$, accelerating tissue remodeling and would healing of gastric mucosa. in a broad spectrum of eosinophilic disorders remain to be elucidated, e.g., idiopathic hypereosinophilic syndrome [128] and some eosinophilic skin diseases such as eosinophilic fasciitis, eosinophilic cellulitis, and eosinophilic pustular folliculitis [39].

A fascinating question is the possible relationship between eosinophils, helminth parasitic infection, and protection of autoimmunity. The recent finding that treatment with the parasitic FHES achieves clinical improvement in EAE mice, as mentioned in 'Regulating Other Activities in the Immune System', has demonstrated an essential role of eosinophils in this helminth parasites-induced therapeutic effect on autoimmunity [72]. Interestingly, two recent publications reported that treatment with the phosphorylcholine from certain parasitic helminths can lead to improved clinical findings of autoimmune diseases in murine models of lupus nephritis and those of collagen-induced arthritis $[129,130]$. Is it possible that eosinophils also contribute to this therapeutic effect? Further investigation will be needed to unveil the exact role of eosinophils in helminth-elicited protection against autoimmunity. Genetically engineered mouse models depleted of eosinophils could be of great value for further investigations $[8,22]$; however, we should be cautious when applying the conclusion from mice studies in humans.

\section{Acknowledgments}

This work was supported by the National Natural Science Foundation of China (No. 81220108017, No. 81430074, No. 81301357 and No. 30972745), the Ph.D. Programs Foundation of Ministry of Education of China (No. 20120162130003), the Hunan Provincial Natural Science Foundation of China (13JJ4025 and 14JJ1009), and the National Key Clinical Specialty Construction Project of National Health and Family Planning Commission of the People's Republic of China.

\section{Disclosure Statement}

The authors declare that they have no conflict of interest. 


\section{References}

1 Gleich GJ, Adolphson CR: The eosinophilic leukocyte: structure and function. Adv Immunol 1986;39:177253.

- Furuta GT, Atkins FD, Lee NA, Lee JJ: Changing roles of eosinophils in health and disease. Ann Allergy Asthma Immunol 2014;113:3-8.

$\checkmark 3$ Rosenberg HF, Dyer KD, Foster PS: Eosinophils: changing perspectives in health and disease. Nat Rev Immunol 2013;13:9-22.

4 Kita H: Eosinophils: Multifaceted biological properties and roles in health and disease. Immunol Rev 2011; 242:161-177.

5 Shamri R, Xenakis JJ, Spencer LA: Eosinophils in innate immunity: an evolving story. Cell Tissue Res 2011; 343:57-83.

6 Kita H: Eosinophils: Multifunctional and distinctive properties. Int Arch Allergy Immunol 2013;2:3-9.

7 Hogan SP, Rosenberg HF, Moqbel R, Phipps S, Foster PS, Lacy P, Kay AB, Rothenberg ME: Eosinophils: biological properties and role in health and disease. Clin Exp Allergy 2008;38:709-750.

8 Rothenberg ME, Hogan SP: The eosinophil. Annu Rev Immunol 2006;24:147-174.

$\checkmark$ Goldman M, Le Moine A, Braun M, Flamand V, Abramowicz D: A role for eosinophils in transplant rejection. Trends Immunol 2001;22:247-251.

10 Samoszuk M: Eosinophils and human cancer. Histol Histopathol 1997;12:807-812.

11 Gatault S, Legrand F, Delbeke M, Loiseau S, Capron $\mathrm{M}$ : Involvement of eosinophils in the anti-tumor response. Cancer Immunol Immunother 2012;61:15271534.

12 Davis BP, Rothenberg ME: Eosinophils and cancer. Cancer Immunol Res 2014;2:1-8.

13 Moqbel R, Lacy P: New concepts in effector functions of eosinophil cytokines. Clin Exp Allergy 2000;30: 1667-1671.

14 Lacy P, Moqbel R: Eosinophil cytokines. Chem Immunol 2000;76:134-155.

15 Acharya KR, Ackerman SJ: Eosinophil granule proteins: form and function. J Biol Chem 2014;289:1740617415.

16 Gessner A, Mohrs K, Mohrs M: Mast cells, basophils, and eosinophils acquire constitutive IL-4 and IL-13 transcripts during lineage differentiation that are sufficient for rapid cytokine production. J Immunol 2005; 174:1063-1072.

17 Wang YH, Angkasekwinai P, Lu N, Voo KS, Arima K, Hanabuchi S, Hippe A, Corrigan CJ, Dong C, Homey B, Yao Z, Ying S, Huston DP, Liu YJ: IL-25 augments type 2 immune responses by enhancing the expansion and functions of TSLP-DC-activated Th2 memory cells. J Exp Med 2007;204:1837-1847.

18 Medoff BD, Thomas SY, Luster AD: T cell trafficking in allergic asthma: the ins and outs. Annu Rev Immunol 2008;26:205-232.

19 Aceves SS, Ackerman SJ: Relationships between eosinophilic inflammation, tissue remodeling, and fibrosis in eosinophilic esophagitis. Immunol Allergy Clin North Am 2009;29:197-211.

20 Lotfi R, Herzog GI, DeMarco RA, Beer-Stolz D, Lee JJ, Rubartelli A, Schrezenmeier H, Lotze MT: Eosinophils oxidize damage-associated molecular pattern molecules derived from stressed cells. J Immunol 2009;183: 5023-5031.

21 Kvarnhammar AM, Cardell LO: Pattern-recognition receptors in human eosinophils. Immunology 2012; 136:11-20.

22 Liao W, Long H, Chang CC-C, Lu Q: The eosinophil in health and disease: from bench to bedside and back. Clin Rev Allergy Immunol 2015:1-15.
3 Beninati W, Derdak S, Dixon PF, Grider DJ, Strollo DC, Hensley RE, Lucey DR: Pulmonary eosinophils express HLA-DR in chronic eosinophilic pneumonia. J Allergy Clin Immunol 1993;92:442-449.

24 Tamura N, Ishii N, Nakazawa M, Nagoya M, Yoshinari M, Amano T, Nakazima H, Minami M: Requirement of CD80 and CD86 molecules for antigen presentation by eosinophils. Scand J Immunol 1996;44:229-238.

25 Ohkawara Y, Lim KG, Xing Z, Glibetic M, Nakano K, Dolovich J, Croitoru K, Weller PF, Jordana M: CD40 expression by human peripheral blood eosinophils. J Clin Invest 1996;97:1761-1766.

26 Nutku E, Aizawa H, Hudson SA, Bochner BS: Ligation of siglec-8: a selective mechanism for induction of human eosinophil apoptosis. Blood 2003;101:50145020 .

27 Hall S, Agrawal DK: Key mediators in the immunopathogenesis of allergic asthma. Int Immunopharmacol 2014;23:316-329.

28 Kennedy JL, Borish L: Chronic sinusitis pathophysiology: the role of allergy. Am J Rhinol Allergy 2013;27: 367-371.

29 Abonia JP, Rothenberg ME: Eosinophilic esophagitis: rapidly advancing insights. Annu Rev Med 2011;63: 421-434.

30 Blanchard C: Molecular pathogenesis of eosinophilic esophagitis. Curr Opin Gastroenterol 2015;31:321327.

31 DeBrosse C, Rothenberg M: Allergy and eosinophilassociated gastrointestinal disorders (EGID). Curr Opin Immunol 2008;20:703-708.

32 Mehta P, Furuta G: Eosinophils in gastrointestinal disorders: eosinophilic gastrointestinal diseases, celiac disease, inflammatory bowel diseases, and parasitic infections. Immunol Allergy Clin North Am 2015;35: 413-437.

33 de Graauw E, Beltraminelli H, Simon HU, Simon D: Eosinophilia in dermatologic disorders. Immunol Allergy Clin North Am 2015;35:545-560.

34 Bandeira-Melo C, Hall J, Penrose J, Weller P: Cysteinyl leukotrienes induce IL-4 release from cord blood-derived human eosinophils. J Allergy Clin Immunol 2002; 109:975-979.

35 O'Donnell MC, Ackerman SJ, Gleich GJ, Thomas LL: Activation of basophil and mast cell histamine release by eosinophil granule major basic protein. J Exp Med 1983;157:1981-1991.

36 Padigel UM, Hess JA, Lee JJ, Lok JB, Nolan TJ, Schad GA, Abraham D: Eosinophils act as antigen-presenting cells to induce immunity to Strongyloides stercoralis in mice. J Infect Dis 2007;196:1844-1851.

37 Herbert DR, Lee JJ, Lee NA, Nolan TJ, Schad GA, Abraham D: Role of IL-5 in innate and adaptive immunity to larval Strongyloides stercoralis in mice. J Immunol 2000;165:4544-4551.

38 Fulkerson PC, Fischetti CA, Rothenberg ME: Eosinophils and CCR3 regulate interleukin-13 transgene-induced pulmonary remodeling. Am J Pathol 2006;169: 2117-2126.

39 Long H, Zhang G, Wang L, Lu Q: Eosinophilic skin diseases: a comprehensive review. Clin Rev Allergy Immunol 2015;2015:16.

40 Aceves SS, Broide DH: Airway fibrosis and angiogenesis due to eosinophil trafficking in chronic asthma. Curr Mol Med 2008;8:350-358.

41 Ohno I, Lea RG, Flanders KC, Clark DA, Banwatt D, Dolovich J, Denburg J, Harley CB, Gauldie J, Jordana M: Eosinophils in chronically inflamed human upper airway tissues express transforming growth factor beta 1 gene (TGF beta 1). J Clin Invest 1992;89:1662-1668.

42 Aceves SS: Remodeling and fibrosis in chronic eosinophil inflammation. Dig Dis 2014;32:15-21.
3 Hoshino M, Takahashi M, Aoike N: Expression of vascular endothelial growth factor, basic fibroblast growth factor, and angiogenin immunoreactivity in asthmatic airways and its relationship to angiogenesis. J Allergy Clin Immunol 2001;107:295-301.

44 Chu VT, Frohlich A, Steinhauser G, Scheel T, Roch T, Fillatreau S, Lee JJ, Lohning M, Berek C: Eosinophils are required for the maintenance of plasma cells in the bone marrow. Nat Immunol 2011;12:151-159.

45 Chu VT, Beller A, Rausch S, Strandmark J, Zanker M, Arbach O, Kruglov A, Berek C: Eosinophils promote generation and maintenance of immunoglobulin-aexpressing plasma cells and contribute to gut immune homeostasis. Immunity 2014;40:582-593.

46 Chen HH, Sun AH, Ojcius DM, Hu WL, Ge YM, Lin X, Li LJ, Pan JP, Yan J: Eosinophils from murine lamina propria induce differentiation of naive $\mathrm{T}$ cells into regulatory $\mathrm{T}$ cells via TGF-betal and retinoic acid. PLoS One 2015;10:e0142881.

47 Yamada T, Tani Y, Nakanishi H, Taguchi R, Arita M, Arai H: Eosinophils promote resolution of acute peritonitis by producing proresolving mediators in mice. FASEB J 2011;25:561-568

48 Masterson JC, McNamee EN, Fillon SA, Hosford L, Harris R, Fernando SD, Jedlicka P, Iwamoto R, Jacobsen E, Protheroe C, Eltzschig HK, Colgan SP, Arita M, Lee JJ, Furuta GT: Eosinophil-mediated signalling attenuates inflammatory responses in experimental colitis. Gut 2015;64:1236-1247.

49 Throsby M, Herbelin A, Pleau JM, Dardenne M: $\mathrm{CD} 11 \mathrm{C}+$ eosinophils in the murine thymus: developmental regulation and recruitment upon MHC class Irestricted thymocyte deletion. J Immunol 2000;165: 1965-1975.

50 Lee JJ, Dimina D, Macias MP, Ochkur SI, McGarry MP, O'Neill KR, Protheroe C, Pero R, Nguyen T, Cormier SA, Lenkiewicz E, Colbert D, Rinaldi L, Ackerman SJ, Irvin CG, Lee NA: Defining a link with asthma in mice congenitally deficient in eosinophils.

Science 2004;305:1773-1776.
51 Fulkerson PC, Fischetti CA, McBride ML, Hassman LM, Hogan SP, Rothenberg ME: A central regulatory role for eosinophils and the eotaxin/CCR3 axis in chronic experimental allergic airway inflammation. Proc Natl Acad Sci U S A 2006;103:16418-16423.

52 Walsh ER, Sahu N, Kearley J, Benjamin E, Kang BH, Humbles A, August A: Strain-specific requirement for eosinophils in the recruitment of $\mathrm{T}$ cells to the lung during the development of allergic asthma. J Exp Med 2008;205:1285-1292.

53 Jacobsen EA, Ochkur SI, Pero RS, Taranova AG, Protheroe CA, Colbert DC, Lee NA, Lee JJ: Allergic pulmonary inflammation in mice is dependent on eosinophil-induced recruitment of effector T cells. J Exp Med 2008;205:699-710.

54 Chu DK, Jimenez-Saiz R, Verschoor CP, Walker TD, Goncharova S, Llop-Guevara A, Shen P, Gordon ME, Barra NG, Bassett JD, Kong J, Fattouh R, McCoy KD, Bowdish DM, Erjefalt JS, Pabst O, Humbles AA, Kolbeck R, Waserman S, Jordana M: Indigenous enteric eosinophils control DCs to initiate a primary Th2 immune response in vivo. J Exp Med 2014;211:16571672.

55 Hansel TT, De Vries IJ, Carballido JM, Braun RK, Carballido-Perrig N, Rihs S, Blaser K, Walker C: Induction and function of eosinophil intercellular adhesion molecule-1 and HLA-DR. J Immunol 1992;149:2130-2136.

56 Weller PF, Rand TH, Barrett T, Elovic A, Wong DT, Finberg RW: Accessory cell function of human eosinophils. hla-dr-dependent, MHC-restricted antigen-presentation and IL-1 alpha expression. J Immunol 1993; 150:2554-2562. 
57 Lucey DR, Nicholson-Weller A, Weller PF: Mature human eosinophils have the capacity to express HLA DR. Proc Natl Acad Sci U S A 1989;86:1348-1351.

58 Mawhorter SD, Kazura JW, Boom WH: Human eosinophils as antigen-presenting cells: Relative efficiency for superantigen- and antigen-induced CD4+ T-cell proliferation. Immunology 1994;81:584-591.

59 Celestin J, Rotschke O, Falk K, Ramesh N, Jabara H, Strominger J, Geha RS: IL-3 induces b7.2 (CD86) expression and costimulatory activity in human eosinophils. J Immunol 2001;167:6097-6104.

60 Mawhorter SD, Pearlman E, Kazura JW, Boom WH: Class II major histocompatibility complex molecule expression on murine eosinophils activated in vivo by Brugia malayi. Infect Immun 1993;61:5410-5412.

61 Duez C, Dakhama A, Tomkinson A, Marquillies P, Balhorn A, Tonnel AB, Bratton DL, Gelfand EW: Migration and accumulation of eosinophils toward regional lymph nodes after airway allergen challenge. J Allergy Clin Immunol 2004;114:820-825.

62 Padigel UM, Lee JJ, Nolan TJ, Schad GA, Abraham D: Eosinophils can function as antigen-presenting cells to induce primary and secondary immune responses to Strongyloides stercoralis. Infect Immun 2006;74:32323238.

63 Del Pozo V, De Andres B, Martin E, Cardaba B, Fernandez JC, Gallardo S, Tramon P, Leyva-Cobian F, Palomino P, Lahoz C: Eosinophil as antigen-presenting cell: Activation of $\mathrm{T}$ cell clones and $\mathrm{T}$ cell hybridoma by eosinophils after antigen processing. Eur J Immunol 1992;22:1919-1925.

64 Shi HZ: Eosinophils function as antigen-presenting cells. J Leukoc Biol 2004;76:520-527.

65 Wang HB, Ghiran I, Matthaei K, Weller PF: Airway eosinophils: Allergic inflammation recruited professional antigen-presenting cells. J Immunol 2007;179: 7585-7592.

66 Sabin EA, Pearce EJ: Early IL-4 production by non$\mathrm{CD} 4+$ cells at the site of antigen deposition predicts the development of a T helper 2 cell response to Schistosoma mansoni eggs. J Immunol 1995;155:4844-4853.

67 Shinkai K, Mohrs M, Locksley RM: Helper T cells regulate type-2 innate immunity in vivo. Nature 2002;420: 825-829.

68 Yang D, Chen Q, Su SB, Zhang P, Kurosaka K, Caspi RR, Michalek SM, Rosenberg HF, Zhang N, Oppenheim JJ: Eosinophil-derived neurotoxin acts as an alarmin to activate the TLR2-MyD88 signal pathway in dendritic cells and enhances Th2 immune responses. J Exp Med 2008;205:79-90.

69 Odemuyiwa SO, Ghahary A, Li Y, Puttagunta L, Lee JE, Musat-Marcu S, Moqbel R: Cutting edge: Human eosinophils regulate $\mathrm{T}$ cell subset selection through indoleamine 2,3-dioxygenase. J Immunol 2004; 173: 5909-5913.

70 Shim EJ, Chun E, Lee HS, Bang BR, Cho SH, Min KU, Park HW: Eosinophils modulate CD4(+) T cell responses via high mobility group box-1 in the pathogenesis of asthma. Allergy Asthma Immunol Res 2015; 7:190-194.

71 Wang HB, Weller PF: Pivotal advance: eosinophils mediate early alum adjuvant-elicited $\mathrm{B}$ cell priming and IgM production. J Leukoc Biol 2008;83:817-821.

72 Finlay CM, Stefanska AM, Walsh KP, Kelly PJ, Boon L, Lavelle EC, Walsh PT, Mills KH: Helminth products protect against autoimmunity via innate type $2 \mathrm{cy}$ tokines IL-5 and IL-33, which promote eosinophilia. J Immunol 2016;196:703-714.
73 Weir M, Hall-Craggs M, Shen S, Posner J, Alongi S, Dagher F, Sadler J: The prognostic value of the eosinophil in acute renal allograft rejection. Transplantation 1986;41:709-712.

74 Almirall J, Campistol J, Sole M, Andreu J, Revert L: Blood and graft eosinophilia as a rejection index in kidney transplant. Nephron 1993;65:304-309.

75 Kormendi F, Amend W: The importance of eosinophil cells in kidney allograft rejection. Transplantation 1988; 45:537-539.

76 Foster P, Sankary H, Hart M, Ashmann M, Williams J: Blood and graft eosinophilia as predictors of rejection in human liver transplantation. Transplantation 1989; 47:72-74.

77 Nagral A, Ben-Ari Z, Dhillon A, Burroughs A: Eosinophils in acute cellular rejection in liver allografts. Liver Transpl Surg 1998;4:355-362.

78 Yousem S: Graft eosinophilia in lung transplantation. Hum Pathol 1992;23:1172-1177.

79 Le Moine A, Surquin M, Demoor F-X, Noël J-C, Nahori M-A, Pretolani M, Flamand V, Braun MY, Goldman M, Abramowicz D: IL-5 mediates eosinophilic rejection of MHC class II-disparate skin allografts in mice. J Immunol 1999;163:3778-3784.

80 Braun M, Desalle F, Le Moine A, Pretolani M, Matthys P, Kiss R, Goldman M: IL-5 and eosinophils mediate the rejection of fully histoincompatible vascularized cardiac allografts: regulatory role of alloreactive CD8(+) T lymphocytes and IFN-gamma. Eur J Immunol 2000;30:1290-1296.

81 Cravedi P, Lessman DA, Heeger PS: Eosinophils are not required for the induction and maintenance of an alloantibody response. Am J Transplant 2013;13:26962702.

82 de Groen P, Kephart G, Gleich G, Ludwig J: The eosinophil as an effector cell of the immune response during hepatic allograft rejection. Hepatology 1994;20: 654-662.

83 Csencsits K, Wood S, Lu G, Magee J, Eichwald E, Chang C, Bishop D: Graft rejection mediated by CD4+ $\mathrm{T}$ cells via indirect recognition of alloantigen is associated with a dominant Th2 response. Eur J Immunol 2005;35:843-851.

84 Arbon KS, Albers E, Kemna M, Law S, Law Y: Eosinophil count, allergies, and rejection in pediatric heart transplant recipients. J Heart Lung Transplant 2015; 34:1103-1111.

85 Nolan C, Saenz K, Thomas C, Murphy K: Role of the eosinophil in chronic vascular rejection of renal allografts. Am J Kidney Dis 1995;26:634-642.

86 Lotfi R, Lotze MT: Eosinophils induce DC maturation, regulating immunity. J Leukoc Biol 2008;83:456-460.

87 Le Moine A, Flamand V, Demoor F, Noël J, Surquin M, Kiss R, Nahori M, Pretolani M, Goldman M, Abramowicz D: Critical roles for IL-4, IL-5, and eosinophils in chronic skin allograft rejection. J Clin Invest 1999;103:1659-1667.

88 Kato A, Favoreto S Jr, Avila PC, Schleimer RP: TLR3and Th2 cytokine-dependent production of thymic stromal lymphopoietin in human airway epithelial cells. J Immunol 2007;179:1080-1087.

89 Allakhverdi Z, Comeau MR, Jessup HK, Yoon BR, Brewer A, Chartier S, Paquette N, Ziegler SF, Sarfati M, Delespesse G: Thymic stromal lymphopoietin is released by human epithelial cells in response to $\mathrm{mi}$ crobes, trauma, or inflammation and potently activates mast cells. J Exp Med 2007;204:253-258.

90 Cianferoni A, Spergel J: The importance of TSLP in allergic disease and its role as a potential therapeutic target. Expert Rev Clin Immunol 2014;10:1463-1474.
91 Soumelis V, Reche PA, Kanzler H, Yuan W, Edward G, Homey B, Gilliet M, Ho S, Antonenko S, Lauerma A, Smith K, Gorman D, Zurawski S, Abrams J, Menon S, McClanahan T, de Waal-Malefyt R, Bazan F, Kastelein RA, Liu YJ: Human epithelial cells trigger dendritic cell mediated allergic inflammation by producing TSLP. Nat Immunol 2002;3:673-680.

92 Sano Y, Masuda K, Tamagawa-Mineoka R, Matsunaka H, Murakami Y, Yamashita R, Morita E, Katoh $\mathrm{N}$ : Thymic stromal lymphopoietin expression is increased in the horny layer of patients with atopic dermatitis. Clin Exp Immunol 2013;171:330-337.

93 Kimura S, Pawankar R, Mori S, Nonaka M, Masuno S, Yagi T, Okubo K: Increased expression and role of thymic stromal lymphopoietin in nasal polyposis. Allergy Asthma Immunol Res 2011;3:186-193.

94 Shikotra A, Choy DF, Ohri CM, Doran E, Butler C, Hargadon B, Shelley M, Abbas AR, Austin CD, Jackman J, Wu LC, Heaney LG, Arron JR, Bradding P: Increased expression of immunoreactive thymic stromal lymphopoietin in patients with severe asthma. J Allergy Clin Immunol 2012;129:104-111.

95 Ying S, O'Connor B, Ratoff J, Meng Q, Fang C, Cousins D, Zhang G, Gu S, Gao Z, Shamji B, Edwards MJ, Lee TH, Corrigan CJ: Expression and cellular provenance of thymic stromal lymphopoietin and chemokines in patients with severe asthma and chronic obstructive pulmonary disease. J Immunol 2008; 181:2790-2798.

96 Gao PS, Rafaels NM, Mu D, Hand T, Murray T, Boguniewicz M, Hata T, Schneider L, Hanifin JM, Gallo RL, Gao L, Beaty TH, Beck LA, Leung DY, Barnes KC: Genetic variants in thymic stromal lymphopoietin are associated with atopic dermatitis and eczema herpeticum. J Allergy Clin Immunol. 2010;125:1403-1407.

97 Cook EB, Stahl JL, Schwantes EA, Fox KE, Mathur SK: IL-3 and TNFalpha increase thymic stromal lymphopoietin receptor (TSLPR) expression on eosinophils and enhance TSLP-stimulated degranulation. Clin Mol Allergy 2012;10:1476-7961.

-98 Jessup HK, Brewer AW, Omori M, Rickel EA, Budelsky AL, Yoon BR, Ziegler SF, Comeau MR: Intradermal administration of thymic stromal lymphopoietin induces a T cell- and eosinophil-dependent systemic Th2 inflammatory response. J Immunol 2008;181: 4311-4319.

99 Hui CC, Rusta-Sallehy S, Asher I, Heroux D, Denburg JA: The effects of thymic stromal lymphopoietin and IL-3 on human eosinophil-basophil lineage commitment: relevance to atopic sensitization. Immun Inflamm Dis 2014;2:44-55.

100 Morshed M, Yousefi S, Stockle C, Simon HU, Simon D: Thymic stromal lymphopoietin stimulates the formation of eosinophil extracellular traps. Allergy 2012; 67:1127-1137.

101 Milovanovic M, Volarevic V, Radosavljevic G, Jovanovic I, Pejnovic N, Arsenijevic N, Lukic ML: IL-33/ST2 axis in inflammation and immunopathology. Immunol Res 2012;52:89-99.

102 Schmitz J, Owyang A, Oldham E, Song Y, Murphy E, McClanahan TK, Zurawski G, Moshrefi M, Qin J, Li X, Gorman DM, Bazan JF, Kastelein RA: IL-33, an interleukin-1-like cytokine that signals via the IL-1 receptor-related protein ST2 and induces T helper type 2-associated cytokines. Immunity 2005;23:479-490.

103 Carriere V, Roussel L, Ortega N, Lacorre DA, Americh L, Aguilar L, Bouche G, Girard JP: IL-33, the IL-1like cytokine ligand for ST2 receptor, is a chromatinassociated nuclear factor in vivo. Proc Natl Acad Sci U S A 2007;104:282-287. 
104 Gudbjartsson DF, Bjornsdottir US, Halapi E, Helgadottir A, Sulem P, Jonsdottir GM, Thorleifsson G, Helgadottir $\mathrm{H}$, Steinthorsdottir V, Stefansson H, Williams C, Hui J, Beilby J, Warrington NM, James A, Palmer LJ, Koppelman GH, Heinzmann A, Krueger M, Boezen HM, Wheatley A, Altmuller J, Shin HD, Uh ST, Cheong HS, Jonsdottir B, Gislason D, Park CS, Rasmussen LM, Porsbjerg C, Hansen JW, Backer V, Werge T, Janson C, Jonsson UB, Ng MC, Chan J, So WY, Ma R, Shah SH, Granger CB, Quyyumi AA, Levey AI, Vaccarino V, Reilly MP, Rader DJ, Williams MJ, van Rij AM, Jones GT, Trabetti E, Malerba G, Pignatti PF, Boner A, Pescollderungg L, Girelli D, Olivieri O, Martinelli N, Ludviksson BR, Ludviksdottir D, Eyjolfsson GI, Arnar D, Thorgeirsson G, Deichmann K, Thompson PJ, Wjst M, Hall IP, Postma DS, Gislason T, Gulcher J, Kong A, Jonsdottir I, Thorsteinsdottir U, Stefansson K: Sequence variants affecting eosinophil numbers associate with asthma and myocardial infarction. Nat Genet 2009;41:342-347.

105 Torgerson DG, Ampleford EJ, Chiu GY, Gauderman WJ, Gignoux CR, Graves PE, Himes BE, Levin AM, Mathias RA, Hancock DB, Baurley JW, Eng C, Stern DA, Celedon JC, Rafaels N, Capurso D, Conti DV, Roth LA, Soto-Quiros M, Togias A, Li X, Myers RA, Romieu I, Van Den Berg DJ, Hu D, Hansel NN, Hernandez RD, Israel E, Salam MT, Galanter J, Avila PC, Avila L, Rodriquez-Santana JR, Chapela R, Rodriguez-Cintron W, Diette GB, Adkinson NF, Abel RA, Ross KD, Shi M, Faruque MU, Dunston GM, Watson HR, Mantese VJ, Ezurum SC, Liang L, Ruczinski I, Ford JG, Huntsman S, Chung KF, Vora H, Calhoun WJ, Castro M, Sienra-Monge JJ, del Rio-Navarro B, Deichmann KA, Heinzmann A, Wenzel SE, Busse WW, Gern JE, Lemanske RF, Jr., Beaty TH, Bleecker ER, Raby BA, Meyers DA, London SJ, Gilliland FD, Burchard EG, Martinez FD, Weiss ST, Williams LK, Barnes KC, Ober C, Nicolae DL: Meta-analysis of genome-wide association studies of asthma in ethnically diverse North American populations. Nat Genet 2011;43:887-892.

106 Prefontaine D, Lajoie-Kadoch S, Foley S, Audusseau S, Olivenstein R, Halayko AJ, Lemiere C, Martin JG, Hamid Q: Increased expression of IL-33 in severe asthma: evidence of expression by airway smooth muscle cells. J Immunol 2009;183:5094-5103.

107 Oboki K, Ohno T, Kajiwara N, Arae K, Morita H, Ishii A, Nambu A, Abe T, Kiyonari H, Matsumoto K, Sudo K, Okumura K, Saito H, Nakae S: IL-33 is a crucial amplifier of innate rather than acquired immunity. Proc Natl Acad Sci U S A 2010;107:1858118586.

108 Zhiguang X, Wei C, Steven R, Wei D, Wei Z, Rong M, Zhanguo L, Lianfeng Z: Over-expression of IL-33 leads to spontaneous pulmonary inflammation in MIL-33 transgenic mice. Immunol Lett 2010;131: 159-165.

109 Suzukawa M, Koketsu R, Iikura M, Nakae S, Matsumoto K, Nagase H, Saito H, Matsushima K, Ohta K, Yamamoto K, Yamaguchi M: Interleukin-33 enhances adhesion, CD11b expression and survival in human eosinophils. Lab Invest 2008;88:1245-1253.

110 Chow JY, Wong CK, Cheung PF, Lam CW: Intracellular signaling mechanisms regulating the activation of human eosinophils by the novel Th2 cytokine IL33: implications for allergic inflammation. Cell Mol Immunol 2010;7:26-34.
111 Pecaric-Petkovic T, Didichenko SA, Kaempfer S, Spiegl N, Dahinden CA: Human basophils and eosinophils are the direct target leukocytes of the novel IL-1 family member IL-33. Blood 2009;113:15261534 .

112 Holmes DA, Yeh JH, Yan D, Xu M, Chan AC: DUSP5 negatively regulates IL-33-mediated eosinophil survival and function. EMBO J 2015;34:218-235.

113 Stolarski B, Kurowska-Stolarska M, Kewin P, Xu D, Liew FY: IL-33 exacerbates eosinophil-mediated airway inflammation. J Immunol 2010;185:3472-3480.

114 Liu X, Li M, Wu Y, Zhou Y, Zeng L, Huang T: AntiIL-33 antibody treatment inhibits airway inflammation in a murine model of allergic asthma. Biochem Biophys Res Commun 2009;386:181-185.

115 Lei Y, Boinapally V, Zoltowska A, Adner M, Hellman L, Nilsson G: Vaccination against IL-33 inhibits airway hyperresponsiveness and inflammation in a house dust mite model of asthma. PLoS One 2015;10: 1371 .

116 McGovern TW, Talley NJ, Kephart GM, Carpenter HA, Gleich GJ: Eosinophil infiltration and degranulation in Helicobacter pylori-associated chronic gastritis. Dig Dis Sci 1991;36:435-440.

117 Aydemir SA, Tekin IO, Numanoglu G, Borazan A, Ustundag Y: Eosinophil infiltration, gastric juice and serum eosinophil cationic protein levels in Helicobacter pylori-associated chronic gastritis and gastric ulcer. Mediators Inflamm 2004;13:369-372.

118 Genta RM, Lew GM, Graham DY: Changes in the gastric mucosa following eradication of Helicobacter pylori. Mod Pathol 1993;6:281-289.

119 Nagy TA, Allen SS, Wroblewski LE, Flaherty DK, Slaughter JC, Perez-Perez G, Israel DA, Peek RM Jr: Helicobacter pylori induction of eosinophil migration is mediated by the cag pathogenicity island via microbial-epithelial interactions. Am J Pathol 2011;178: 1448-1452.

120 Peek RM, Jr., Blaser MJ: Helicobacter pylori and gastrointestinal tract adenocarcinomas. Nat Rev Cancer 2002;2:28-37.

121 Parker H, Keenan JI: Composition and function of Helicobacter pylori outer membrane vesicles. Microbes Infect 2012;14:9-16.

122 Ko SH, Jeon JI, Kim YJ, Yoon HJ, Kim H, Kim N, Kim JS, Kim JM: Helicobacter pylori outer membrane vesicle proteins induce human eosinophil degranulation via a beta2 integrin CD11/CD18- and ICAM1-dependent mechanism. Mediators Inflamm 2015; 2015:4.

123 Prevete N, Rossi FW, Rivellese F, Lamacchia D, Pelosi C, Lobasso A, Necchi V, Solcia E, Fiocca R, Ceppa P, Staibano S, Mascolo M, D'Argenio G, Romano M, Ricci V, Marone G, De Paulis A: Helicobacter pylori $\mathrm{hp}(2-20)$ induces eosinophil activation and accumulation in superficial gastric mucosa and stimulates VEGF-alpha and TGF-beta release by interacting with formyl-peptide receptors. Int J Immunopathol Pharmacol 2013;26:647-662.

124 Chung KF: Targeting the interleukin pathway in the treatment of asthma. Lancet 2015;386:1086-1096.

125 Kiwamoto T, Kawasaki N, Paulson J, Bochner B: Siglec- 8 as a drugable target to treat eosinophil and mast cell-associated conditions. Pharmacol Ther 2008; 135:327-336
126 Amini-Vaughan ZJ, Martinez-Moczygemba M, Huston DP: Therapeutic strategies for harnessing human eosinophils in allergic inflammation, hypereosinophilic disorders, and cancer. Curr Allergy Asthma Rep 2012;12:402-412.

127 Walsh G: Mepolizumab-based therapy in asthma: an update. Curr Opin Allergy Clin Immunol 2015;15: 392-396.

128 Hsieh FH: Hypereosinophilic syndrome. Ann Allergy Asthma Immunol 2014;112:484-488.

129 Bashi T, Shovman O, Fridkin M, Volkov A, Barshack I, Blank M, Shoenfeld Y: Novel therapeutic compound tuftsin-phosphorylcholine attenuate collagen induced arthritis. Clin Exp Immunol 2015; doi 10.1111/cei.12745

130 Bashi T, Blank M, Ben-Ami Shor D, Fridkin M, Versini M, Gendelman O, Volkov A, Barshak I, Shoenfeld Y: Successful modulation of murine lupus nephritis with tuftsin-phosphorylcholine. J Autoimmun 2015; 59:1-7.

131 Cadman ET, Thysse KA, Bearder S, Cheung AY, Johnston AC, Lee JJ, Lawrence RA: Eosinophils are important for protection, immunoregulation and pathology during infection with nematode microfilariae. PLoS Pathog 2014;10:e1003988.

132 Reiman RM, Thompson RW, Feng CG, Hari D, Knight R, Cheever AW, Rosenberg HF, Wynn TA: Interleukin-5 (IL-5) augments the progression of liver fibrosis by regulating IL-13 activity. Infect Immun 2006;74:1471-1479.

133 Matsuwaki Y, Wada K, White TA, Benson LM, Charlesworth MC, Checkel JL, Inoue Y, Hotta K, Ponikau JU, Lawrence CB, Kita H: Recognition of fungal protease activities induces cellular activation and eosinophil-derived neurotoxin release in human eosinophils. J Immunol 2009;183:6708-6716.

134 Yoon J, Ponikau JU, Lawrence CB, Kita H: Innate antifungal immunity of human eosinophils mediated by a beta 2 integrin, CD11b. J Immunol 2008;181:29072915.

135 Yousefi S, Gold JA, Andina N, Lee JJ, Kelly AM, Kozlowski E, Schmid I, Straumann A, Reichenbach J, Gleich GJ, Simon HU: Catapult-like release of mitochondrial DNA by eosinophils contributes to antibacterial defense. Nat Med 2008;14:949-953.

136 Domachowske JB, Dyer KD, Bonville CA, Rosenberg HF: Recombinant human eosinophil-derived neurotoxin/RNAse 2 functions as an effective antiviral agent against respiratory syncytial virus. J Infect Dis 1998;177:1458-1464.

137 Li Y, Zhao Y, Liu J, Huang Y, Liu Z, Xue C: A promising alternative anti-HBV agent: the targeted ribonuclease. Int J Mol Med 2010;26:51-56.

138 Phipps S, Lam CE, Mahalingam S, Newhouse M, Ramirez R, Rosenberg HF, Foster PS, Matthaei KI: Eosinophils contribute to innate antiviral immunity and promote clearance of respiratory syncytial virus. Blood 2007;110:1578-1586.

139 Dyer K, Percopo C, Fischer E, Gabryszewski S, Rosenberg H: Pneumoviruses infect eosinophils and elicit MyD88-dependent release of chemoattractant cytokines and interleukin-6. Blood 2009;114:26492656.

140 Handzel ZT, Busse WW, Sedgwick JB, Vrtis R, Lee
(1) WM, Kelly EA, Gern JE: Eosinophils bind rhinovirus and activate virus-specific T cells. J Immunol 1998; 160:1279-1284. 